UDC 579

DOI: $10.15587 / 2519-8025.2021 .241865$

\title{
MORPHOLOGICAL AND ANATOMICAL PROPERTIES OF VERONICA CRISTA-GALLI STEVEN
}

\author{
Nigar Pashayeva, Tahir Suleymanov, Yusif Kerimov, Eldar Qasimov, Fuad Rzayev
}

\begin{abstract}
The aim of this work was to study of diagnostic signs of the morphological and anatomical structure of Veronica crista-galli Steven. from the flora of Azerbaijan.

Materials and methods. The samples for research were collected during their flowering time in June 2018, in the Ismailli region of the Republic of Azerbaijan. Plant samples were fixed in a solution made in 0.1 M phosphate buffer (pH=7.4), containing $2.5 \%$ glutar-aldehyde, $2.5 \%$ paraformal-aldehyde and $0.1 \%$ picric acid. In the next stage was the preparation of block and their filling in Araldite - Epon according to the TEM method.

Results. The leaf is simple, lower part is short-petiolate and upper is sessile. The surface, on both sides of the leaf, is reliefly, and 7-8 conductive veins are clearly visible. The lower and upper sides of the leaf, and also margin, are strewn with multicellular hairs. The calyx of the flower consists of two sepals which grown together at the base, covered with simple multicellular hairs. The stalk in is a long filiform. The corolla of flower consists of 4 petals which grown together at the base and 2 stamens attached to the tube of the corolla. On the epidermis, cells with sinuous and bead-like walls, numerous stomata of the stavrocytic type, capitate hairs are visible. From the cross section of the leaf, it is visible that palisade tissue at the upper and sponge tissue at the bottom.

Conclusions. As a result of morphological and anatomical studies, it was revealed that diagnostic signs of plant raw material can be: Present of multicellular hairs on the leaf blade; The location of the capsule between the sepals; Stavrocytic type of the stoma structure; The bead-like walls of the epidermis; Capitate hairs on the epidermis; Sepals covered by hairs.

The established anatomical diagnostic features can be used for the drafting of the normative document on the plant raw materials and for identification of plant raw material of Veronica crista-galli
\end{abstract}

Keywords: Veronica crista-galli Stev., leaf, flower, fruit

How to cite:

Pashayeva, N., Suleymanov, T., Kerimov, Y., Qasimov, E., Rzayev, F. (2021). Morphological and anatomical properties of Veronica crista-galli Steven. ScienceRise: Biological Science, 3 (28), 15-20. doi: http://doi.org/10.15587/2519-8025.2021.241865

(C) The Author(s) 2021

This is an open access article under the Creative Commons CC BY license hydrate

\section{Introduction}

Medicinal Plants and Herbal Medicines are widely practiced in modern medicine, and phyto-drugs basis nearly 40 percent of the pharmaceutical industry. The demand of the medicinal raw materials at the worldwide is increasing every year. Therefore, searching for different and new types of medicinal plants, raw materials and their uses is an urgent task of pharmaceutical science. The Azerbaijan has a varied and rich vegetation cover. More than 4,000 species of plants in Azerbaijan, and it is necessary that 135 species of these are officially recognized as medicinal plants [1].

Veronica L. officinalis is naturalized of countries Tibet and Romanian folk medicine. Traditional medicine for the treatment of various conditions. Phytocemically, Veronica cilicata officinalis has showed the presence of irridoids and phenolic compounds and also posseses antibacterial, antioxidant, anti-inflammatory and cytotoxic and antiulcer activities [2-6].

One of the insufficiently explored genus of the domestic flora is Veronica L. The plants from this genus are used for the treatment of various inflammatory diseases include including rheumatism, hepatitis, cholecystitis and urticaria, for the treatment of lung diseases, also for the treatment of various diseases [3, $6]$.

It was studied that the $V$. Teucrium and $V$. Jacquinini gives best beneficial effects for Alzheimer's diseases and Parkinsons diseases [7].

Founded that, the cytotoxic activity of some native species has been determined for several cancer cell. Natural therapies, such as the use of plant devided products in cancer chemotherapy may reduce adverse side effects [8].

The anti-cancer characteristics of a number of plants are still being actively researched and some have shown promising results. Phytochemical studied of various extracts from vegetables Veronica L. have recently been a great interest in the field of pharmacological research in different countries and the raw materials contains flavonoids, hydroxycoric acids, coumarins, iridoids, etc. biologically active compound [3].

Within this frame, this study aimed to investigate the phytochemical researches of aerial parts of relevant Veronica species harvested from the Azerbaijan spontaneous flora $[9,10]$ and as a result of which prospective species have been identified for replenishing the arsenal of medicinal plants. İnteresting point of this research is 
the establishment of diagnostic features of the anatomical structure of Veronica crista-galli raw materials.

The aim of this work was to study morphological and anatomical structure of Veronica crista-galli Steven.

\section{Materials and methods}

The samples for research were collected during their flowering time in June 2018, in the Ismailli region of the Republic of Azerbaijan. Plant samples were fixed in a solution made in $0.1 \mathrm{M}$ phosphate buffer ( $\mathrm{pH}=7.4)$, containing $2.5 \%$ glutar-aldehyde, 2.5 $\%$ paraformal-aldehyde and $0.1 \%$ picric acid. Samples have been postfixed in $1 \%$-osmium tetraoxide solution prepared in phosphate buffer $(\mathrm{pH} 7.4)$ after being left in the same fixer for one day. Then, the materials was dehydrated. In this case, each sample was conditionally passed three times within 15 minutes (only 45 minutes), followed with 50 percent ,70 percent and 96 percent of the alcohol solution.

The pieces were washed three times during 15 minutes (45 minutes each) in a solution containing 50 $\%$ pure alcohol and $50 \%$ pure acetone, and then rewashed in pure acetone three times for 15 minutes (only 45 minutes). In the next stage was the preparation of block and their filling in Araldite - Epon according to the generally accepted methodology TEM method $[11,12]$.

Araldide-Epon solution used a mixture of 5 substances (Epon-812, DDSA, Araldid M, Dibutalftalat and DMP-30). Their weight ratios varies depending on the number of samples, for example for the preparation of 10 $\mathrm{ml}$ of Araldide-Epon solution, the following composition ratio should be chosen: $2.5 \mathrm{ml}$ - Epon-812; $5.5 \mathrm{ml}-$ DDSA; $1.5 \mathrm{ml}$ - Araldid M; $0.3 \mathrm{ml}$ - DMP-30; 7 DMP-30 droplet. The preparatory phase of the cluster is divided into several parts:

a) $75 \%$ of the solution is acetone and $25 \%$ araldid-ephon

b) $50 \%$ solution is acetone and $50 \%$ araldid-epon

c) $25 \%$ solution is acetone and $75 \%$ araldidephon

d) Samples are contained in $100 \%$ araldid-epon for 1 hour.

After the final phase, the samples were placed in pre-selected and numbered finished forms. The samples were stored in the thermostat during the 1 day at $37^{\circ} \mathrm{C}$, then 1 day at $45{ }^{\circ} \mathrm{C}$ and 1 day at $60{ }^{\circ} \mathrm{C}$ (3 days). Semiand Ulstra-thin cuttings were produced by the ultramicrotome Leica EM UC7. The semithin slices (1-2 $\mu \mathrm{m})$ were colored with trichromic staining (methylene blue, azur II and fuxin) by F. D'Amico (2005) (178) and studied under the light microscope Primo Star (Zeiss, Germany). The process image were photographed by the digital camera Canon D 650 (Japan).

\section{Results}

The leaf is simple, lower is short-petiolate and upper is sessile. The shapes of the leaf margins are serrate the leaf shape is ovoid, the venation type is arcuate. The surface, on both sides of the leaf, is reliefly, and 7-8 conductive veins are clearly visible (Fig. 1).

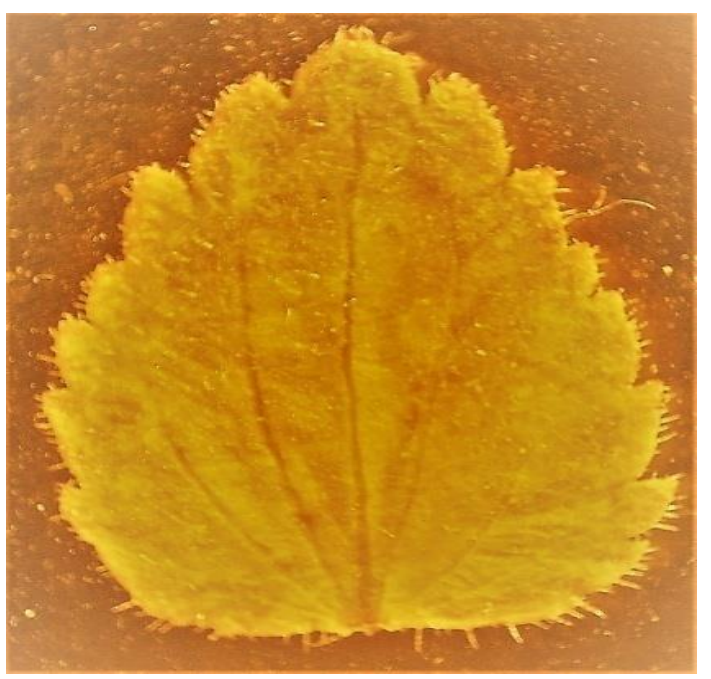

$a$

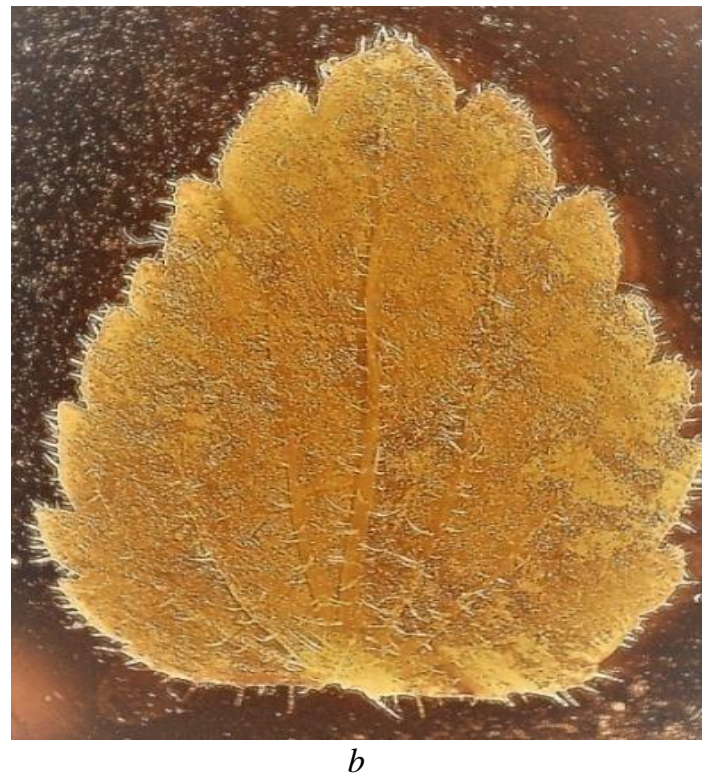

Fig. 1. The sides of leaf blade: $a$ - upper side; $b$ - lower side

The lower and upper sides of the leaf, and also margin, are strewn with multicellular hairs. Often to see the places of broken hairs at the margin of the leaf. The hairs on the veins from lower leaf side are significantly thicker at the junction of the petiole with the stem. At the junction of the leaf with stem densely planted hairs are presented (Fig. 2).

The calyx of the flower consists of two sepals which grown together at the base, covered with simple multicellular hairs. Each sepal consists of like two wedge-shaped lobes (Fig. 3).

The stalk in is a long filiform. The corolla of flower consists of 4 petals which grown together at the base and 2 stamens attached to the tube of the corolla.

The capsule is located between the sepals and hairs are arranged along the entire surface (Fig 4.)

On the epidermis, cells with sinuous and bead-like walls, numerous stomata of the stavrocytic type, capitate hairs are visible (Fig 5) 


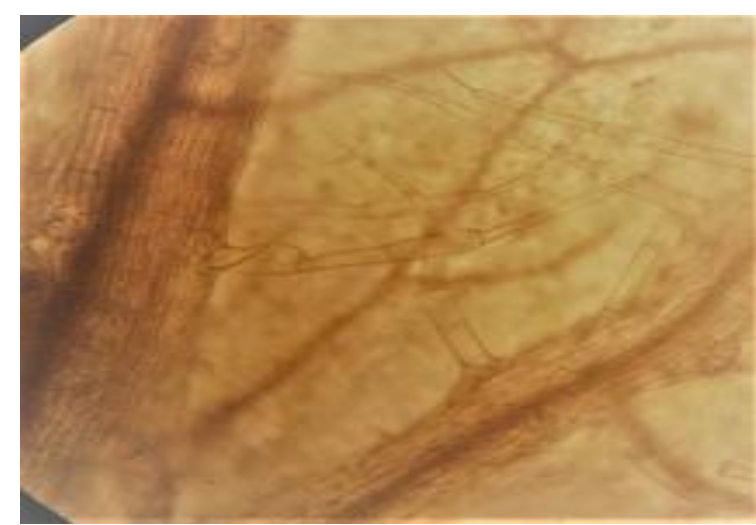

a

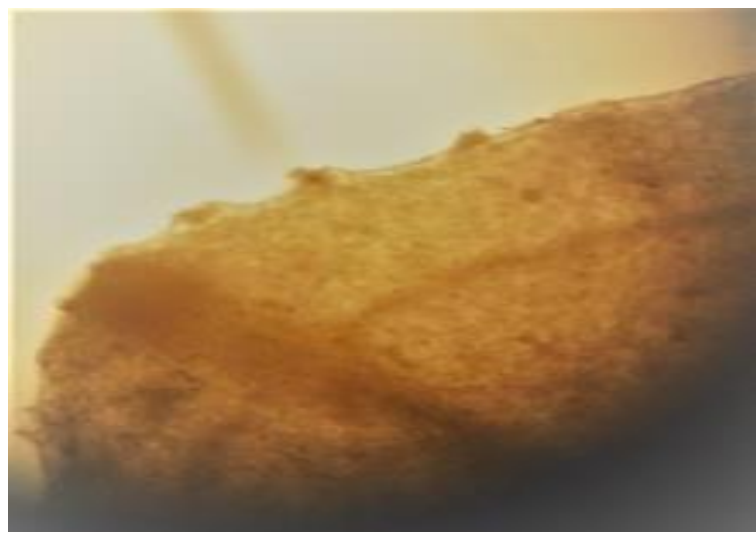

$c$

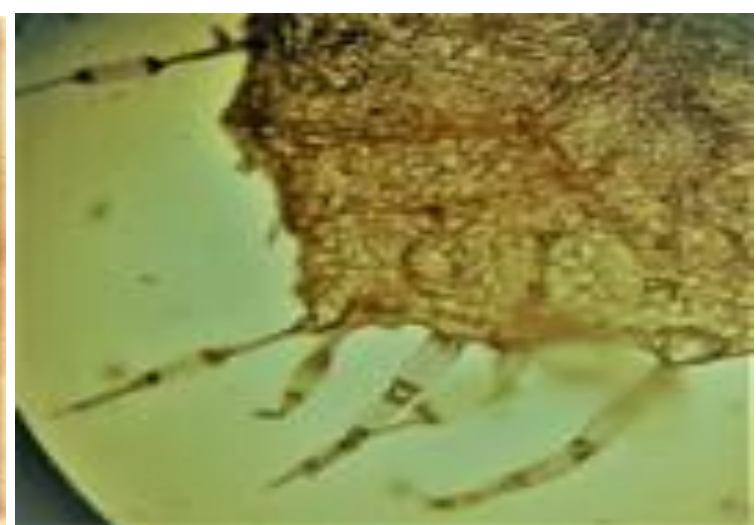

b

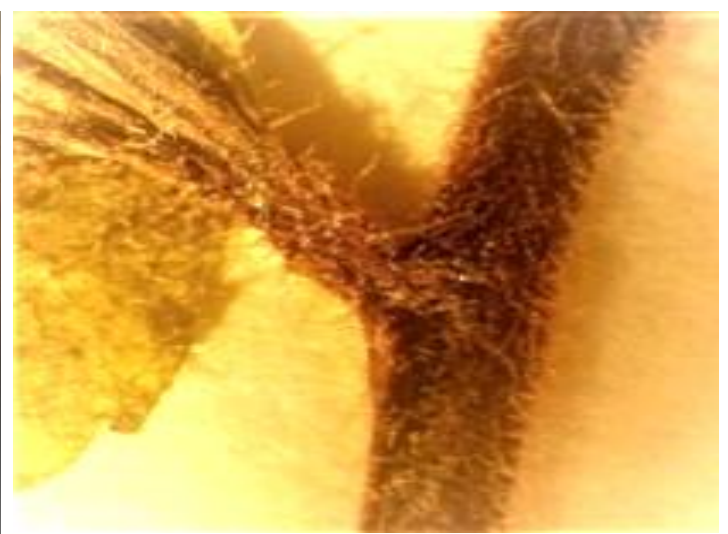

$d$

Fig. 2. Hairs of the leaf: $a$ - the hairs on the veins; $b$ - the hairs at the leaf margins; $c$ - the places of broken hairs; $d$ - the hairs at the junction of the leaf with stem

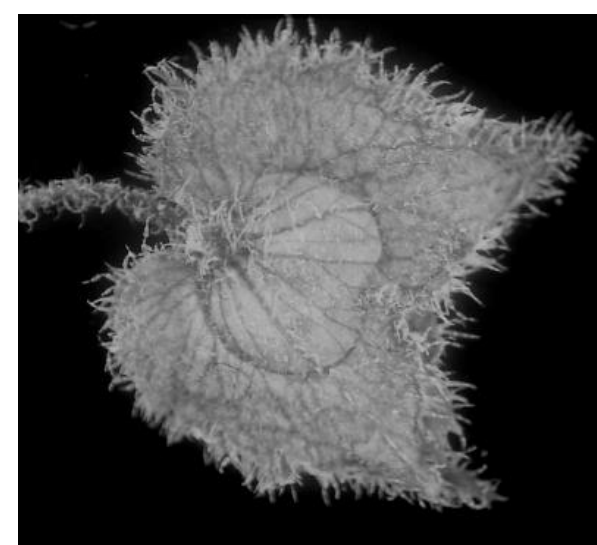

a

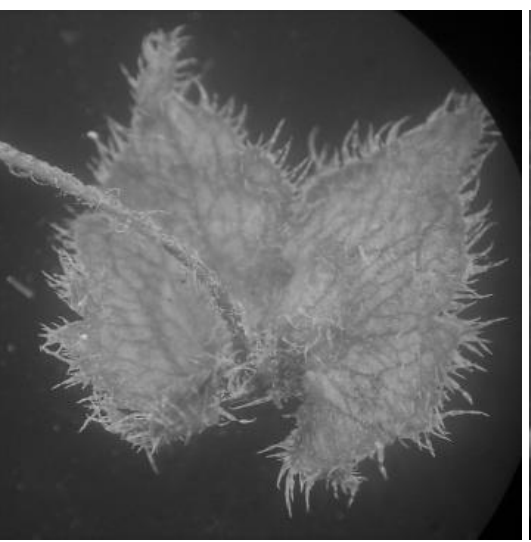

b

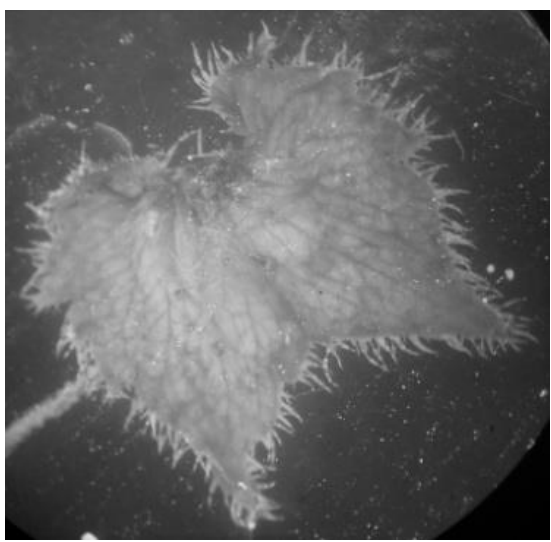

c

Fig. 3. Sepal of the flower: $a$ - capsule on a stalk between sepals; $b$ - sepal outside; $c$ - sepal inside 


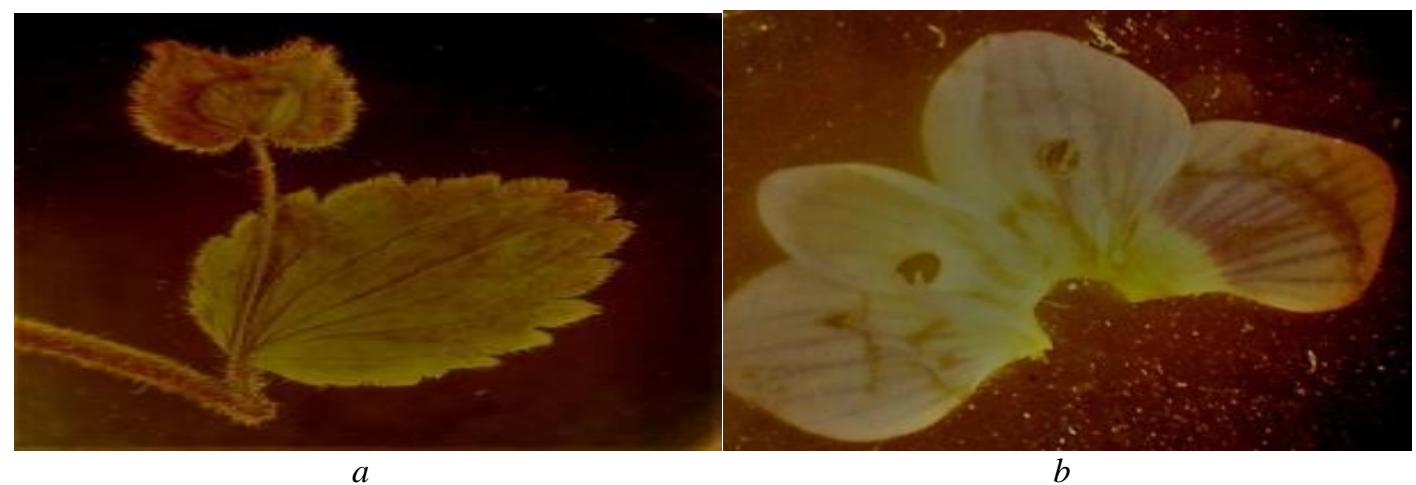

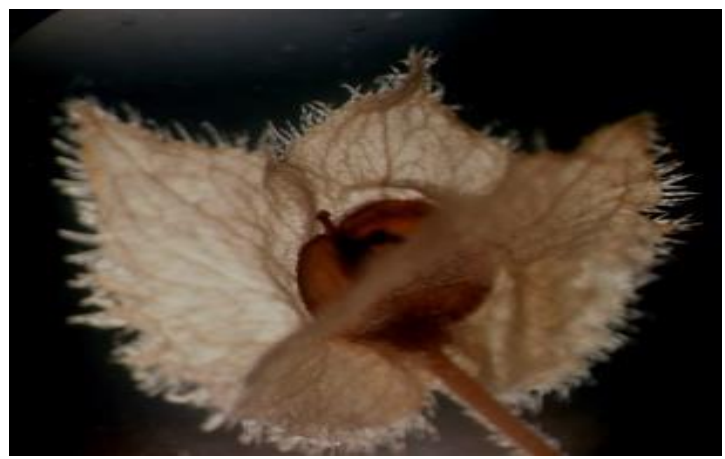

$c$

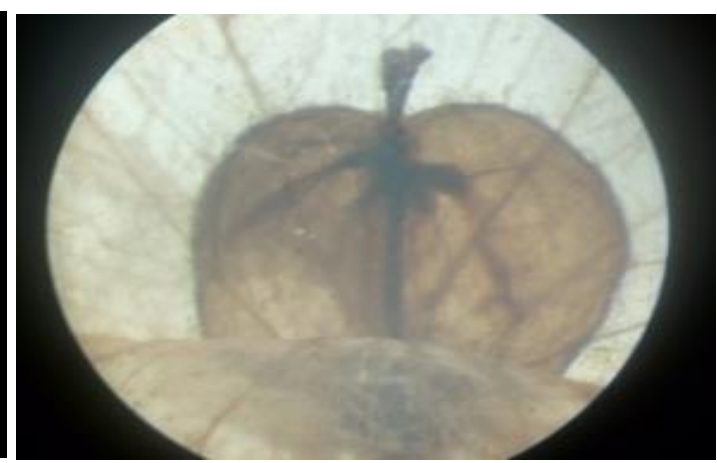

$d$

Fig. 4. Flower with fruit: $a$-stalk with a calyx; $b$-corolla with stamens; $c$-capsule between sepals; $d$-capsule with hairs along a circle

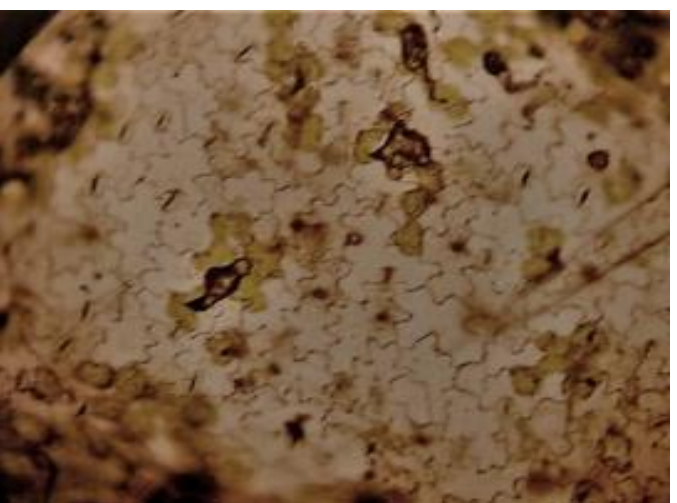

$a$

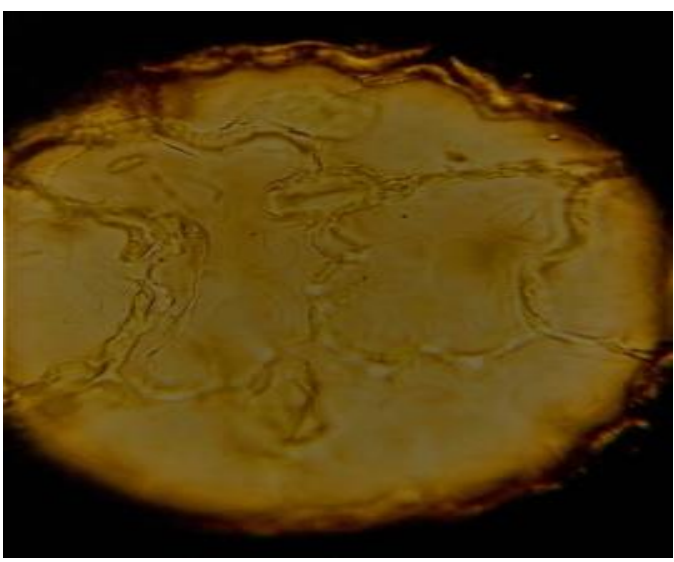

$c$

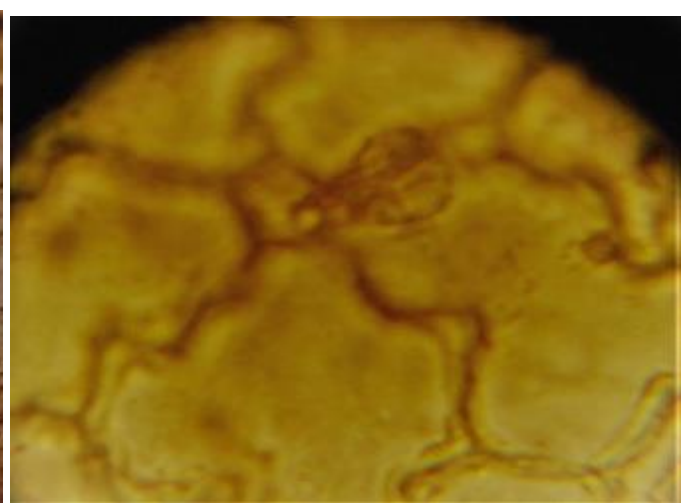

$b$

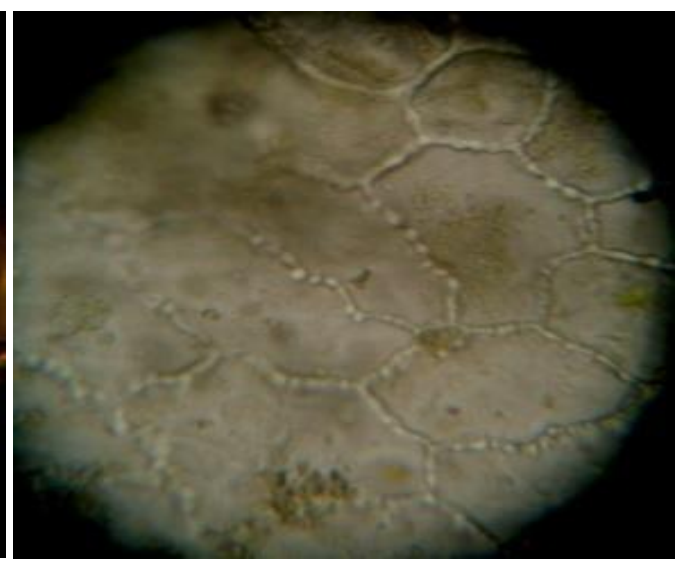

$d$

Fig. 5. The leaf epidermis: $a$ - The epidermis cell with stomata; $b$ - capitate hairs 
From the cross section of the leaf, it is visible that palisade tissue at the upper and sponge tissue at the bottom. There are conductive bundles, and also a single-cell capitate hair on the epidermis are visible. Judging by the location of the tissues, the structure of the leaf is twosided type.

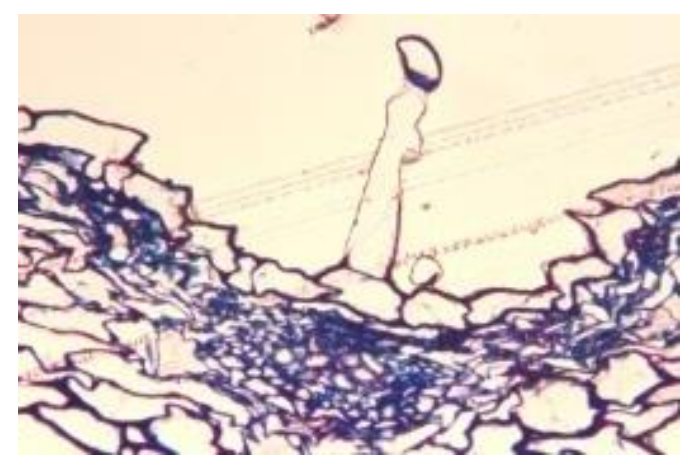

$a$

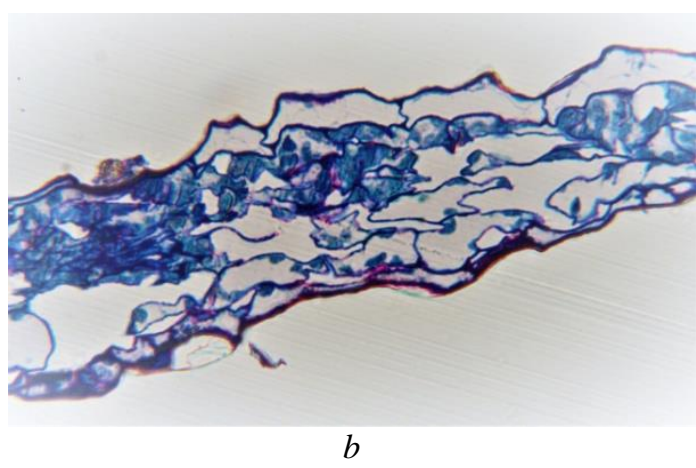

Fig. 6. Cross-section of leaf blade: $a$ - conductive bundle and hair; $b$ - palisade and sponge tissues

\section{Discussion}

In the morphological and anatomic studying of the raw material of Veronica crista-galli Steven showed that there are characteristic diagnostic signs in the structure. We have not found any information about the literature on the microscopic studying of the raw material of Veronica crista-galli. Some of the microscopic features for standardizing of the plant material of the genus of Veronica ( $V$. anagills-aquatica L., V. multifida, V. anagilloides L., $V$. cymbalaria bod. etc.) were established $[13,14]$.
This is the first report on the exanimated characteristics of the V. ctista-galli in the flora Azerbaijan. Transverse section of the stems of the plant was studied for its microscopic characters.

The leaf is simple, lower is short-petiolate and upper is sessile. The surfaces of the leaf, on both sides, are relief, and 7-8 conductive veins are clearly visible. The lower and upper sides of the leaf, and also margin, are strewn with multicellular hairs. The calyx of the flower consists of two sepals which are grown together at the base, covered with simple multicellular hairs. The stalk is long and filiform.

Research limitations. It is known that the determination of the identity of medicinal plant raw materials is carried out mainly based on the characteristic diagnostic features of the morphological and anatomical structure. But, at present, taxonomy is based on the genetic characteristics of the plant. In the future it is possible that this research will be completed in this direction.

Prospects for further research. Morphological and anatomical characteristics might be useful in the definition of the investigated species. These characteristics are more valuable if the other species of Veronica will be investigated.

\section{Conclusions}

As a result of morphological and anatomical studies, it was revealed that diagnostic signs of plant raw material can be:

- Present of multicellular hairs on the leaf blade.

- The location of the capsule between the sepals

- Stavrocytic type of the stoma structure.

- The bead-like walls of the epidermis

- Capitate hairs on the epidermis

- Sepals covered by hairs

The established anatomical diagnostic features can be used for the drafting of the normative document on the plant raw materials and for identification of plant raw material of Veronica crista-galli.

\section{Conflicts of interest}

The authors declare that they have no conflicts of interest.

Financing

The study was performed without financial support.

\section{References}

1. Kerimov, Yu., Suleimanov, T. (2016). Na sobstvennoi syrevoi baze. Vestnik Natsionalnoi Akademii Nauk Azerbaidzhana, $19-22$.

2. Akanda, M. R., Nam, H.-H., Tian, W., Islam, A., Choo, B.-K., Park, B.-Y. (2018). Regulation of JAK2/STAT3 and NF-кB signal transduction pathways; Veronica polita alleviates dextran sulfate sodium-induced murine colitis. Biomedicine \& Pharmacotherapy, 100, 296-303. doi: http://doi.org/10.1016/j.biopha.2018.01.168

3. Dunkić, V., Kosalec, I., Kosir, I., Potocnik, T., Cerenak, A., Koncic, M. et. al. (2015). Antioxidant and antimicrobial properties of Veronica spicata L. (Plantaginaceae). Current Drug Targets, 16 (14), 1660-1670. doi: http://doi.org/10.2174/1389450116666150531161820

4. Saracoglu, I., Oztunca, F. H., Nagatsu, A., Harput, U. S. (2011). Iridoid content and biological activities ofVeronica cuneifoliasubsp.cuneifoliaandV. cymbalaria. Pharmaceutical Biology, 49 (11), 1150-1157. doi: http://doi.org/10.3109/13880209.2011.575790

5. Sun, Y., Lu, Q., He, L., Shu, Y., Zhang, S., Tan, S., Tang, L. (2017). Active Fragment ofVeronica ciliataFisch. Attenuates t-BHP-Induced Oxidative Stress Injury in HepG2 Cells through Antioxidant and Antiapoptosis Activities. Oxidative Medicine and Cellular Longevity, 2017, 1-11. doi: http://doi.org/10.1155/2017/4727151

6. Yin, L., Lu, Q., Tan, S., Ding, L., Guo, Y., Chen, F., Tang, L. (2016). Bioactivity-guided isolation of antioxidant and antihepatocarcinoma constituents from Veronica ciliata. Chemistry Central Journal, 10 (1). doi: http://doi.org/10.1186/s13065-016-0172-1 
7. Kroflič, A., Germ, M., Golob, A., Stibilj, V. (2018). Does extensive agriculture influence the concentration of trace elements in the aquatic plant Veronica anagallis-aquatica? Ecotoxicology and Environmental Safety, 150, 123-128. doi: http://doi.org/10.1016/ j.ecoenv.2017.10.055

8. Saracoglu, I., Harput, U. S. (2011). In Vitro Cytotoxic Activity and Structure Activity Relationships of Iridoid Glucosides Derived from Veronica species. Phytotherapy Research, 26 (1), 148-152. doi: http://doi.org/10.1002/ptr.3546

9. Süleymanov, T. A., Paşayeva, N. H., Stev, V. P., Stev, V. C.-G. (2018). Xammalında spektrofotometrik üsulla flavonoidlərin miqdari təyini. Azərbaycan təbabətinin müasir nailiyyətləri, 8, 121-123.

10. Saracoglu, I., Suleimanov, T., Pashaeva, N., Dogan, Z., Inoue, M., Nakashima, K. (2020). Iridoids from Veronica cristagalli from the Flora of Azerbaijan. Chemistry of Natural Compounds, 56 (4), 751-753. doi: http://doi.org/10.1007/s10600-02003139-3

11. Kuo, J. (2007). Electron microscopy: methods and protocols. Totowa: Humana Press, 625.

12. Agayeva, N. J., Rzayev, F. H., Gasimov, E. K., Mamedov, C. A., Ahmadov, I. S., Sadigova, N. A. et. al. (2020). Exposure of rainbow trout (Oncorhynchus mykiss) to magnetite (Fe3O4) nanoparticles in simplified food chain: Study on ultrastructural characterization. Saudi Journal of Biological Sciences, 27 (12), 3258-3266. doi: http://doi.org/10.1016/j.sjbs.2020.09.032

13. AL-Abide, N. M. (2019). A morphological and anatomical comparative Study of the Reproductive parts of the genusVeronicaL. (Plantaginaceae) in northern Iraq. Journal of Physics: Conference Series, 1294, 062114. doi: http://doi.org/10.1088/1742$6596 / 1294 / 6 / 062114$

14. Kaplan, A., Hasanoglu, A., Agah Ince, I. (2006). Morphological, Anatomical and Palynological Properties of Some Turkish Veronica L. Species (Scrphulariaceae). International Journal of Botany, 3 (1), 23-32. doi: http://doi.org/10.3923/ijb.2007.23.32

Received date 24.07.2021

Accepted date 09.09.2021

Published date 30.09.2021

Nigar Hidayet Pashayeva, PhD Student, Department of Pharmaceutical Chemistry. Azerbaijan Medical University, Anvar Gasim Zadeh 14, Baku, Azerbaijan, AZ1022

Tahir Abbasali Suleymanov, Professor, Head of Department, Department of Pharmaceutical Chemistry, Azerbaijan Medical University, Anvar Gasim Zadeh, 14, Baku, Azerbaijan, AZ1022

Yusif Balakerim Kerimov, Professor, Scientific Adviser, Department of Pharmacognosy, Azerbaijan Medical University, Anvar Gasim Zadeh, 14, Baku, Azerbaijan, AZ1022

Eldar Kocheri Gasimov, Professor, Head of Department, Department of Histology, Embryology and Cytolgy, Azerbaijan Medical University, Anvar Gasim Zadeh, 14, Baku, Azerbaijan, AZ1022

Fuad Huseynali Rzayev, Senior Researcher, Laboratory of Electron Microscopy, Azerbaijan Medical University, Anvar Gasim Zadeh, 14, Baku, Azerbaijan, AZ1022

*Corresponding author: Tahir Abbasali Suleymanov,e-mail: tair63@mail.ru 